\title{
Novel approaches for the identification of biomarkers of aggressive prostate cancer
}

Yunee Kim¹ and Thomas Kislinger*1,2

\begin{abstract}
The ability to distinguish indolent from aggressive prostate tumors remains one of the greatest challenges in the management of this disease. Ongoing efforts to establish a panel of molecular signatures, comprising gene expression profiles, proteins, epigenetic patterns, or a combination of these alterations, are being propelled by rapid advancements in 'omics' technologies. The identification of such biomarkers in biological fluids is an especially attractive goal for clinical applications. Here, we summarize recent progress in the identification of candidate prognostic biomarkers of prostate cancer using biological fluid samples.
\end{abstract}

\section{The search for prognostic biomarkers of prostate cancer}

Accurate and timely assessment of prostate cancer prognosis remains one of the most significant clinical challenges in prostate cancer management. Rapid advances in molecular technologies are likely to lead to significant progress in the foreseeable future. Despite these technological strides and the overwhelming number of proposed biomarkers, prostate cancer is still over-diagnosed and many patients are treated in an unnecessarily aggressive manner. Possible reasons are the complex nature of this disease (which is multi-focal and heterogeneous) leading to frequent misclassification of patients, intra-institutional variability, and patient variability, all of which contribute to the lack of well-defined and validated prognostic biomarkers.

Elevated serum prostate-specific antigen (PSA) levels have been utilized as an indicator of prostatic disease, including prostate cancer. Although PSA screening has

*Correspondence: thomas.kislinger@utoronto.ca

'Department of Medical Biophysics, University of Toronto, Toronto, Canada M5G 1 L7

Full list of author information is available at the end of the article resulted in the detection of lower-risk prostate cancer at earlier and more treatable stages of disease [1], prostate cancer is still the most frequently diagnosed cancer in men in developed countries and remains the second most common cause of cancer-specific mortality [2]. Furthermore, with the advent of large-scale screening for serum PSA, unnecessary biopsies and patient over-treatment are becoming increasingly evident $[3,4]$. The US Preventative Services Task Force has recommended against PSAbased prostate cancer screening on the basis of high false-positive rates and the risks associated with biopsies and over-treatment [5]. Aggressive or advanced cancers can spread quickly and warrant intensive treatment, but up to $90 \%$ of men who have prostate cancer harbor localized disease [6] and many patients are over-treated on the basis of PSA screening [4,7]. The prospective demarcation of patients with indolent tumors from those with aggressive disease is therefore of paramount importance. The identification of biomarkers that can classify patients into high- and low-risk groups, before their cancers reach advanced or metastatic states, is a major area of ongoing research. A biomarker is a measurable biological indicator that can provide information about the presence or progression of a disease or the effects of a given treatment. A clinically useful biomarker should be safely obtainable from the patient by non-invasive means, have high sensitivity and specificity, high positive and negative predictive values, and facilitate clinical decisions that allow optimal care to be administered [8].

Proteomics and integrated genomics approaches have resulted in the identification of numerous putative prognostic biomarkers for prostate cancer. With the recent advances in mass spectrometry technologies especially, proteomes can now be analyzed with impressive coverage. Verification and validation platforms have also improved significantly; mass spectrometry-based assays with multiplexing capability can be established for the targeted quantification of specific peptides of interest. In this review, we begin by summarizing some of the efforts that have been made in various fields to identify prognostic biomarkers for prostate cancer. Following this, we introduce concepts for biomarker discovery in 
bio-fluids that are relevant to prostate cancer and highlight some emerging proteomic approaches and their application to biomarker discovery.

\section{Prostate cancer prognostic biomarkers}

In broad terms, current and proposed alternative or adjunct prognostic markers for prostate cancer can be divided into clinical-pathological features and molecular factors (Table 1). In this section, we briefly summarize existing and recently proposed prognostic biomarkers for prostate cancer. These include the classic pathological scoring system for biopsy specimens, Gleason grading and more recent discoveries, such as molecular features, that might offer insight into disease progression and prognosis.

\section{Classic prognostic biomarkers}

Currently, Gleason grading is considered to be the best predictor of outcome [9]. When using this method, pathologists assign numerical grades (ranging from 1 to 5 , with 5 being the poorest grade) to the two most commonly observed histological patterns, based on the degree of loss of normal glandular tissue. These two grades are summed into a Gleason score. Patients with Gleason scores 7 or higher are at increased risk of extraprostatic extension and recurrence after therapy [10,11]; furthermore, individuals with Gleason $4+3$ tumors (those where pattern 4 is most prevalent but some amount of pattern 3 is also observed) may be at greater risk of prostate cancer-specific mortality than Gleason 3+4 patients (pattern 3 most prevalent but some pattern 4 is also observed) [12]. The multifocal nature of prostate cancer, whereby different genetic alterations may exist in different tumor foci of a prostate, however, increases the likelihood of missing a high-grade focus. Furthermore, the risks associated with biopsies, such as bleeding and increased risk of infections potentially leading to sepsis, underscore the need for alternative approaches for accurate prognosis [13]. The change in PSA levels (that is, PSA velocity) has also been used as a predictor of outcome after treatment; a PSA velocity of greater than $2 \mathrm{ng} / \mathrm{ml} /$ year is associated with a significantly higher risk of prostate-cancer-specific mortality [14].

\section{Cellular markers}

$\mathrm{Ki}-67$ is a nuclear protein that is associated with cellular proliferation [15]. Its immunohistochemical staining index has been correlated with outcome in treated patients [16-19]. Heterogeneous immunohistochemical staining for $\alpha$-methylacyl-coenzyme A racemase (AMACR) has been correlated with Gleason score [20], and low $A M A C R$ gene expression in localized prostate cancer has been linked to recurrence and metastasis [21]. Prostatespecific membrane antigen (PSMA) is a transmembrane protein expressed in all types of prostatic tissue that is used in the diagnosis of prostate cancer [22]. Its overexpression is associated with higher tumor grade, stage, PSA recurrence and metastatic disease [23,24].

\section{Genetic aberrations as prognostic biomarkers}

Focusing on a specific pathway or a group of interrelated genes that are involved in fundamental tumor biology has also proven useful. Cuzick et al. [25] focused on genes involved in cell-cycle progression and measured the mRNA expression of 126 genes in formalin-fixed paraffin-embedded prostate cancer tissues. A 31-gene signature was generated on the basis of their correlation with the mean expression of the entire panel of 126 genes. When used to retrospectively score patients who underwent prostatectomy and patients with localized disease, this signature was shown to predict recurrence after surgery and risk of death in conservatively managed patients, independently of Gleason score and other clinical factors. Using comparative transcriptomic analyses, Ding et al. [26] identified the robust activation of the Tgf $/$ /Bmp-Smad4 signaling pathway in indolent Ptennull mouse prostate tumors. Deletion of Smad4 in the Pten-null mouse prostate led to highly proliferative, invasive, metastatic and lethal tumors. When combined with expression levels of the key molecular players cyclin D1 and osteopontin, a four-gene expression signature (for PTEN, SMAD4 and genes coding for cyclin D1 and osteopontin) could predict biochemical recurrence and supplement the Gleason score in predicting lethal metastasis of prostate cancer in patients.

Genomic variations, such as copy number alterations, have also been linked to diseases including cancer. In a comprehensive genomic analysis of prostate cancer, Taylor and colleagues [27] analyzed copy number alterations in primary prostate tumors and found distinct patient clusters with varying degrees of relapse that had no association with Gleason score. Penney and colleagues [28] constructed a 157-gene signature based on the comparison of Gleason $\leq 6$ and Gleason $\geq 8$ patients. When applied to patients with Gleason 7 scores, their signature improved the prediction of lethality when compared to Gleason score alone.

DNA methylation patterns in prostate cancer may also provide insight into prostate cancer outcome. Cottrell et al. [29] performed a genome-wide scan in patients with early recurrence, high Gleason score or advanced stage; they identified 25 methylation markers that were significantly different between low- and high-Gleasonscore patients. Furthermore, the methylation states of three markers (GPR7, ABHD9 and Chr3-EST) were significantly increased in patients whose tumors reoccurred, as measured by elevated post-prostatectomy PSA levels. 
Table 1. Current and putative prognostic biomarkers for prostate cancer

\begin{tabular}{|c|c|c|}
\hline Marker & Source & Reference(s) \\
\hline \multicolumn{3}{|l|}{ Clinical or pathological characteristics } \\
\hline $\begin{array}{l}\text { High-risk prostate cancer defined as: stage } \mathrm{T}^{\mathrm{c}} \mathrm{c}^{\mathrm{a}} \text { or higher and } \\
\text { PSA }>20 \mathrm{ng} / \mathrm{ml} \text {, or Gleason 8-10 }\end{array}$ & Tissue biopsy, serum & D'Amico et al. [11] \\
\hline PSA velocity & Serum & D'Amico et al. [14] \\
\hline Circulating tumor cells & Whole blood & Kantoff et al. [35], Goodman et al. [36] \\
\hline \multicolumn{3}{|l|}{ Molecular factors } \\
\hline Ki-67 & Prostate tissue & $\begin{array}{l}\text { Berney et al. [16], Khor et al. [17], Bettencourt et al. [18], } \\
\text { Fisher et al. [19] }\end{array}$ \\
\hline a-Methylacyl-CoA-racemase & Prostate tissue & Murphy et al. [20], Rubin et al. [21] \\
\hline Prostate-specific membrane antigen & Prostate tissue & Ross et al. [23], Perner et al. [24] \\
\hline $\begin{array}{l}\text { Urokinase plasminogen activator or Plasminogen activator } \\
\text { inhibitor-1 }\end{array}$ & Prostate tissue & Gupta et al. [30] \\
\hline Transforming growth factor- $\beta$ or interleukin- 6 soluble receptor & Prostate tissue & Shariat et al. [31], Shariat et al. [32] \\
\hline microRNA & Plasma, urine & Porkka et al. [37] \\
\hline Telomerase & Post-prostate massage urinary cells & Meid et al. [55] \\
\hline Annexin A3 & Post-prostate massage urine & Schostak et al. [57] \\
\hline Matrix metalloproteinase 9, 2 & Urine & Roy et al. [59], Di Carlo et al. [60] \\
\hline \multicolumn{3}{|l|}{ Genetic features } \\
\hline Multi-gene panels & Prostate tissue & Cuzick et al. [25], Ding et al. [26], Penney et al. [28] \\
\hline Copy number variations & Prostate tissue & Taylor et al. [27] \\
\hline DNA-methylation patterns & Prostate tissue & Cottrell et al. [29] \\
\hline
\end{tabular}

aStage T2 category refers to tumors that can be felt during a digital rectal exam (DRE) or observed with imaging, but is still confined to the prostate.

\section{Circulating biomarkers}

Urokinase plasminogen activator (uPA) and its inhibitor, PAI-1, have been associated with aggressive prostate cancer exhibiting extraprostatic extension and seminal vesicle invasion, and with post-prostatectomy recurrence in patients with aggressive disease [30]. Preoperative plasma levels of transforming growth factor beta 1 (TGF- $\beta 1$ ) have been shown to be a predictor of biochemical recurrence [31] and, in conjunction with preoperative plasma levels of interleukin 6 receptor (IL-6sR), have been associated with metastasis and progression [32].

Disseminated tumor cells in the bone marrow, a common site of prostate cancer metastasis, have been shown to have an association with metastatic disease and high Gleason score [33,34]. Although disseminated tumor cells may be a prognostic marker of unfavorable outcome in patients with localized disease at diagnosis, attention has shifted to tumor cells that have entered the peripheral blood as these are more easily accessible. The number of circulating tumor cells can be determined at the time of diagnosis and elevated numbers, as indicated by reverse transcriptase polymerase chain reaction for PSA, have been associated with advanced stage and increased Gleason score [35]. Goodman et al. [36] determined that prior to treatment, a cut-off value of 4 circulating tumor cells per $7.5 \mathrm{ml}$ of blood or more was negatively correlated with survival and could predict metastasis.

\section{MicroRNAs}

MicroRNAs (miRNAs) are a class of small, non-coding RNA molecules that are involved in the negative regulation of gene expression. Porkka and colleagues [37] demonstrated distinct miRNA expression profiles of benign prostate hyperplasia, untreated prostate cancers, and hormone-refractory prostate cancers, suggesting a potential prognostic role for miRNAs. Mitchell et al. [38] demonstrated that tumor-derived miRNAs are present in plasma and could show that miR-141 was significantly elevated in the sera of prostate cancer patients, demonstrating the utility of miRNAs as blood-based cancer biomarkers. Khan et al. [39] analyzed localized prostate tumor and adjacent normal tissues, as well as samples from advanced cases, using isobaric tags for relative and absolute quantification (iTRAQ) followed by mass spectrometry. Integrating their findings with a cancer microarray database, these authors identified differentially expressed proteins that are targets of miR-128, a finding that was further supported by in vitro experiments demonstrating a role for miR-128 in prostate cancer invasion [39]. 


\section{Emerging 'omics' approaches}

Alternative strategies for the identification of disease biomarkers include metabolomics and lipidomics. Sreekumar and colleagues [40] undertook a global metabolomic profiling study to look for alterations that are associated with prostate cancer progression using mass spectrometry. Over 1,000 metabolites were identified in over 250 prostate cancer samples (of urine, plasma, and tissue). Sarcosine, an $\mathrm{N}$-methyl derivative of glycine, was found to be elevated in patients with metastatic disease when compared to those with organ-confined tumors and was shown to be involved in prostate cancer invasion. Using a lipidomics approach, Zhou et al. [41] profiled 390 lipid species in plasma from patients with prostate cancer and healthy controls. Of the 390 species, 35 were found to be significantly differentially expressed, and 12 of these were proposed as individual markers of prostate cancer based on a sensitivity above $80 \%$ and specificity above $50 \%$.

\section{Prostate-related proximal tissue fluids}

In the context of protein-based analyses platforms, the potential of serum or plasma as a source of biomarkers is hampered by its immense complexity [42] (Figure 1). The human plasma proteome, for instance, has a dynamic range of protein concentrations in the order of $10^{10}$ for many known proteins [43]; low-abundance species are thus overlooked by currently available technologies (that is, mass spectrometers can detect proteins over a maximum five orders of magnitude). Tissue-proximal fluids are located in close proximity to the tissue of interest and have been proposed as rich sources for biomarker discovery [44]. They house secreted proteins and sloughed cells that provide a potentially comprehensive assessment of the organ and the extent of disease. These fluids include urine, seminal fluid, semen, and expressed prostatic secretions (EPS). EPS exist either as direct-EPS, which are collected from the prostate prior to radical prostatectomy, or as EPS-urine, which is expelled into void urine post-digital rectal examination (DRE). The prostatic urethra carries urine through the prostate and hence may represent a useful source of prostate cancer biomarkers. One major advantage of urine over serum or plasma, with regards to protein biomarker detection, is that its contents remain relatively stable and do not undergo massive proteolytic degradation [45]. Nevertheless, the volume collected may result in varying protein concentrations, highlighting the need for standardized collection protocols.

\section{Biomarkers in urine}

Prostate cancer antigen 3 (PCA3) is a prostate-specific non-coding RNA that was first identified in a comparative transcriptomics study looking at tumor and adjacent normal tissues [46]. Subsequently, a RT-PCR based test was developed to detect PCA3 in urinary EPS [47]. A ratio of the PCA3:PSA RNA, known as the PCA3 score, is used, in combination with other clinical information, to guide decisions on repeat biopsy in men who are 50 years of age or older and who have previously had at least one negative prostate biopsy. Interestingly, Nakanishi et al. [48] reported mean PCA3 score to be significantly lower in patients with low-volume and lowgrade prostate tumors than in those with advanced tumors. The ability of the PCA3 test to predict aggressive prostate cancers is, however, under debate [48-50].

Tomlins et al. [51] first reported the occurrence of a recurrent TMPRSS2:ERG fusion transcript (transmembrane protease serine 2 gene fusion with E twenty-six (ETS) transcription factors) in those with prostate tumors. These fusions were detectable in $42 \%$ of urinary EPS samples from men with prostate cancer [52], although their presence in urinary sediment was not correlated with biopsy Gleason scores [53]. Telomerase is a ribonucleoprotein involved in telomere synthesis and repair [54]. Its activity, which can be measured in urinary EPS using the telomeric repeat amplification protocol assay $[55,56]$, was found to be increased in prostate cancer and has been shown to be associated with Gleason score [55]. Urinary annexin A3 and various matrix metalloproteinases have also been shown to have diagnostic and/ or prognostic potential in prostate cancer [57-60].

Approximately $3 \%$ of the total urinary protein content is composed of exosomal proteins [61], which thus represent a sub-fraction for the discovery of prostate cancer biomarkers $[62,63]$. Exosomes are small vesicles (40 to $100 \mathrm{~nm}$ ) containing protein, RNA and lipids that are secreted by various normal and tumor cells $[63,64]$. Wang et al. [65] used shotgun proteomics to generate the largest catalogue of urinary exosome proteins to date. In their study, over 3,000 unique proteins were identified from samples derived from nine healthy individuals. Exosome secretion is elevated in the biofluids of cancer patients, including those with prostate cancer [66], and exosomes have been shown to be enriched in tumor-cellspecific transcripts $[67,68]$. miRNA and mRNA can be transferred between cells via exosomes and have been shown to be functional in their new location [69]. Nilsson et al. [63] showed, in a proof-of-concept study, that urinary exosomes derived from prostate cancer patients contained two known biomarkers (PCA3 and TMPRSS2:ERG) and thus could be used as sources of biomarkers for disease.

\section{Proteomics in prostate cancer biomarker discovery}

Proteomics approaches allow for high-throughput analyses of complex biological samples, leading to the identification of biomarker candidates (Table 2). A typical cancer biomarker discovery workflow consists of a 


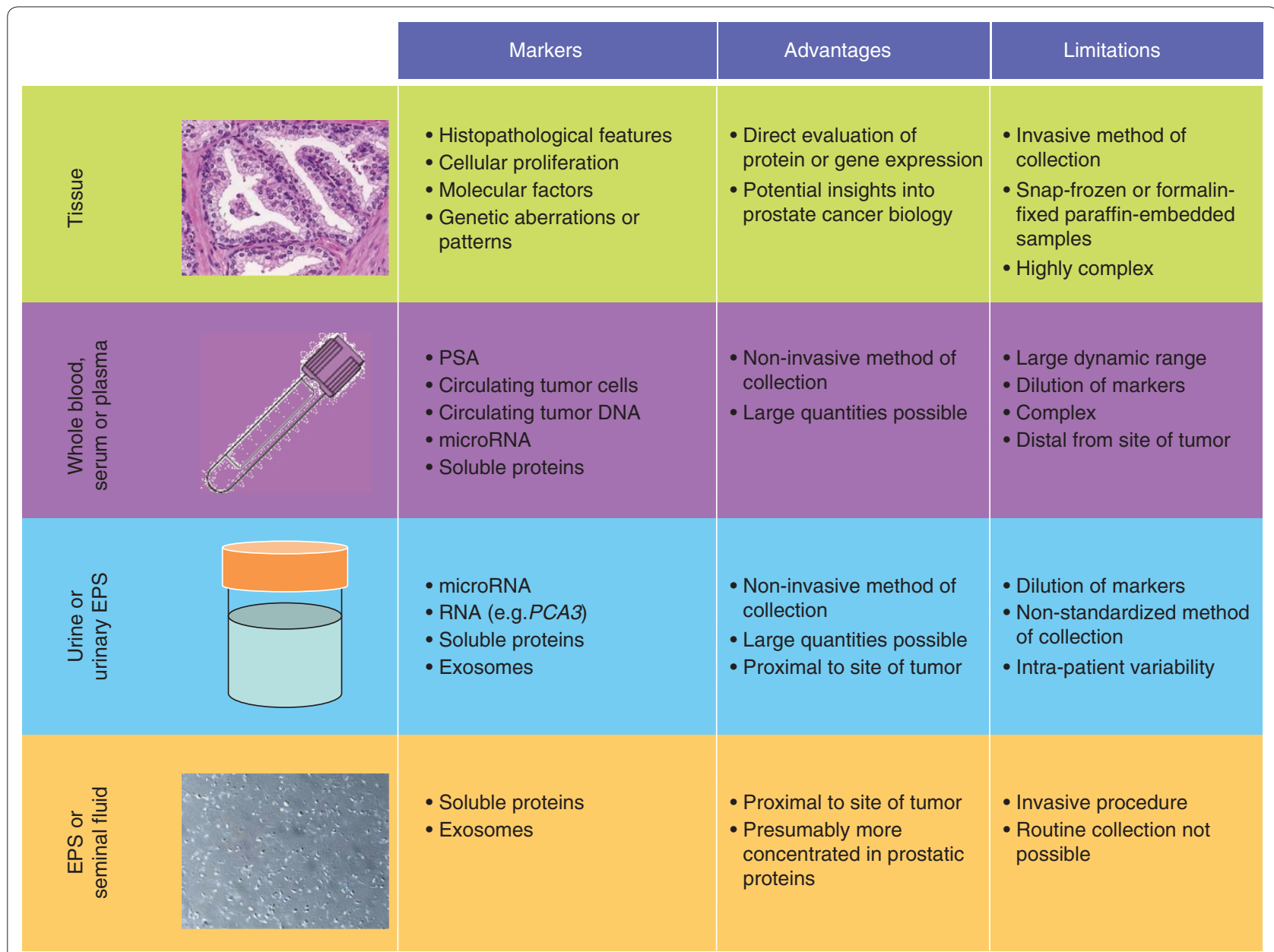

Figure 1. Common sources of prostate cancer biomarkers. These include the conventional biopsy and post-prostatectomy tissue and blood specimens. Prostate-proximal fluids also represent promising sources of soluble factors that can be collected non-invasively.

discovery phase, during which a comprehensive comparative catalogue of candidate proteins is generated. This is followed by verification of candidates using targeted methods of quantification, and finally, validation and clinical assay development [42].

\section{Protein biomarker discovery in prostate-proximal fluids}

Using mass spectrometry, Li et al. [70] identified 114 proteins in the direct-EPS from patients with low- and high-grade prostate cancers, benign prostate hyperplasia and one healthy individual. In a subsequent study, Drake and colleagues [71] used multidimensional protein identification technology [72,73] to analyze direct-EPS from nine prostate cancer patients (Gleason 6 and 7 cancers). Over 900 proteins were identified by Drake et al., 94 of which were also identified in the study of $\mathrm{Li}$ and colleagues [70]. Zhao and colleagues [74] used stableisotope-labeled secretome standards, a technique in which prostate cancer cells (PC3 cell line) were grown in media labeled with heavy stable isotopes and the labeled secreted proteins subsequently used as a standard across 11 direct-EPS samples to identify and quantify 86 proteins simultaneously. Principe et al. [75] performed a comparative study of urine obtained from individuals with or without cancer before and after prostatic massage. A total of 1,022 proteins were identified, of which 49 were found to be prostate-enriched. Furthermore, proteomic analyses of urine by Adachi et al. [76] catalogued over 1,500 proteins in urine from 10 healthy individuals. Seminal fluid may also represent a source of proteins that may be informative about prostate cancer outcome, and thus should be explored for this purpose $[77,78]$. These examples provide an important resource for future biomarker discovery efforts in these important classes of prostate-proximal fluids.

\section{Targeted proteomics}

The validation of candidate protein biomarkers, which includes the task of selectively and reliably quantifying disease-related alterations in protein concentrations, 
Table 2. Recent (2010 to present) putative prognostic biomarkers of prostate cancer discovered using various mass spectrometry platforms

\begin{tabular}{|c|c|c|c|c|}
\hline Proteomic method & Protein biomarker(s) & Sample source & Additional info & References \\
\hline \multirow[t]{5}{*}{ 2D-PAGE + MALDI-TOF/TOF } & Panel of 17 candidates & $\begin{array}{l}\text { Tissue: Gleason score } 5(n=4) \text { compared with } \\
\text { Gleason score } 7(n=4)\end{array}$ & & Alaiya et al. [104] \\
\hline & Panel of 6 candidates & $\begin{array}{l}\text { Tissue: localized }(n=7) \text { compared with lymph node } \\
\text { metastases }(n=1)\end{array}$ & & Pang et al. [105] \\
\hline & Lamin A & $\begin{array}{l}\text { Tissue: low }(n=23) \text { compared with high }(n=23) \\
\text { Gleason }\end{array}$ & $\mathrm{ROC} A \cup C^{\mathrm{a}}=0.88$ & Skvortsov et al. [106] \\
\hline & Transthyretin & Serum: $n=4$ & & Wang et al. [107] \\
\hline & Clusterin & Serum: $n=4$ & & Wang et al. [107] \\
\hline \multirow[t]{5}{*}{ Shotgun proteomics } & Panel of 5 markers & Tissue ( $n=$ unknown) & & Drake et al. [108] \\
\hline & Panel of 3 markers & $\begin{array}{l}\text { Pooled serum: metastases }(n=5) \text { compared with } \\
\text { progressing }(n=5)\end{array}$ & & Rehman et al. [109] \\
\hline & Panel of 7 candidates & $\begin{array}{l}\text { Pooled serum: metastases }(n=5) \text { compared with } \\
\text { progressing }(n=5)\end{array}$ & & Rehman et al. [109] \\
\hline & Panel of 5 markers & $\begin{array}{l}\text { Serum: Gleason }<7(n=27) \text { compared with } \leq 7 \\
(n=27)\end{array}$ & $\operatorname{ROC} A \cup C^{a}=0.79$ & Cima et al. [86] \\
\hline & $\begin{array}{l}\text { Acetyl-coenzyme A } \\
\text { acetyltransferase }\end{array}$ & $\begin{array}{l}\text { Cell lines: androgen-dependent compared with } \\
\text { androgen-independent }\end{array}$ & & Saraon et al. [110] \\
\hline \multirow[t]{2}{*}{ Targeted proteomics } & $\begin{array}{l}\text { Alpha-methylacyl-CoA } \\
\text { racemase }\end{array}$ & Pooled tissue: localized compared with metastases & & Yocum et al. [111] \\
\hline & Enhancer of zeste homolog 2 & Pooled tissue: localized compared with metastases & & Yocum et al. [111] \\
\hline
\end{tabular}

${ }^{a}$ ROC AUC, receiver operating characteristic area under the curve.

remains a major bottleneck. Traditional workflows utilize antibodies for the targeted quantification of such candidates, but caveats associated with antibody development and validation significantly reduce the feasibility of relying on these types of assays for high-throughput biomarker validation. Selected reaction monitoring mass spectrometry (SRM-MS) can be used to develop highly quantitative assays that can complement the more traditional approaches. Although this method is reliably used for quantifying small molecules [79], it has recently been adopted as a robust, sensitive, reproducible and specific assay for protein quantification [80-82]. Several studies have developed SRM-MS for validation of cancer biomarkers, such as biomarkers of bladder cancer in urine [83], biomarkers of ovarian cancer in ascites and serum [84], human lung cancer xenograft lysates in mice [85], and biomarkers of prostate cancer in serum [86].

Quantification by SRM-MS can be achieved by spiking the sample with a known concentration of a stable heavyisotope-labeled peptide standard, which has the same biophysical properties as the endogenous peptide but a difference in mass that is resolved by mass spectrometry. By comparing the peak areas of the endogenous and heavy peptides, the concentration of the endogenous peptide can be inferred. Highly purified and accurately quantified heavy peptides (AQUA ${ }^{\mathrm{m}}$ Peptides, Thermo Scientific) can be used for the absolute quantification of endogenous peptides. These peptides are costly, however, so absolute quantification is reserved for the most promising biomarker candidates. Unlike antibody-based combinatorial detection systems, SRM-MS-based quantification approaches have the advantage of being easily multiplexable, and thus have great potential for success.

Hüttenhain et al. [87] developed a high-throughput workflow for the quantification of cancer-associated proteins in human urine and plasma. Their study, which utilized SRM-MS, tracked 408 urinary proteins. Interestingly, 169 of these were previously undetected in the datasets from the Human Protein Atlas and in the urinary proteome dataset from Adachi et al. [76]. Furthermore, using SRM-MS assays of plasma from patients with ovarian cancer and benign ovarian tumors, Hüttenhain et al. [87] were able to demonstrate the reproducible differential expression of a number of candidates. In another study, Cima and colleagues [86] focused their analyses on the glycoproteome of Pten-null mouse serum and prostate. Label-free comparative analysis of the Pten-null animals and age-matched wildtype mice revealed 111 candidates from the prostate tissue and 12 candidates from the sera that were significantly differentially expressed. Next, these authors utilized SRM-MS assays to reliably quantify the 39 protein orthologs (selected on the basis of consistent quantification) in the sera of prostate cancer patients and controls, and used the resulting profiles to build predictive regression models for the diagnosis and grading of prostate cancer. Our group has also aimed to develop a proteomics-based platform for the discovery 
and subsequent verification of prostate cancer-related proteins $[71,75,88]$. Specifically focusing our attention on prostate-proximal fluids, we have recently identified over 100 protein candidates that are differentially expressed when patients with organ-confined and extraprostatic tumors are compared [88]. A small number of these candidates were also found to be expressed differentially in urinary EPS from patients with recurrent disease (identified on the basis of elevated post-prostatectomy PSA levels) when assayed by stable isotope dilutionSRM-MS. Future studies will be dedicated to the verification of all differentially expressed candidates, using SRM-MS in a medium-sized cohort of urinary EPS samples from clinically stratified prostate cancer patients, in order to demonstrate the application of SRM-MS as a useful verification tool for protein biomarker candidates in these fluids.

Recently, sequential window acquisition of all theoretical fragment-ion spectra mass spectrometry (SWATHMS) has come to the forefront of new developments in mass spectrometry. Relying on data-independent acquisition, and originally described by the Yates group [89], this approach records the fragment ion spectra of all analytes in a sample that fall within a predetermined $\mathrm{m} / \mathrm{z}$ range and retention-time window [89-91]. This approach allows confident identification of peptides over a dynamic range of four orders of magnitude and detects precursor ions that have not been selected in the MS scan by datadependent acquisition [90]. Although the sensitivity of the targeted data analysis coupled to SWATH-MS method is slightly lower than that of SRM-MS, its quantification accuracy rivals that of SRM-MS [90,91], and thus this method could prove to be a powerful platform for biomarker discovery and verification. Advances in mass spectrometry have also led to higherresolution instruments that can allow for the systematic removal of interferences [92-94], allowing improved targeted analyses in complex backgrounds. This can be achieved by mass spectrometry in single ion monitoring (SIM) mode coupled with tandem mass spectrometry (MS/MS), which allows quantification at the MS/MS level. Gallien et al. [94] comparatively assessed the performance of SIM-MS and SRM-MS in analyzing urine and noted similar sensitivities, albeit the SIM-MS analysis was able to quantify a larger number of peptides at the lowest concentrations of spiked-in standards.

Biological fluids are highly complex and efforts in pursuit of complete proteome coverage are underway. Functionalized nanoparticles with high-affinity baits can be used to capture desired classes of proteins, including low-abundance proteins [95-97]. Alternatively, focusing analyses to specific sub-proteomes by exploiting posttranslational modifications can also selectively enrich for desired classes of proteins. One such modification that is commonly used in biomarker discovery efforts is $\mathrm{N}$ linked glycosylation, which is particularly abundant in secreted and membrane proteins. [98]. N-linked glycosylated proteins are captured by a solid support via hydrazide chemistry and then enzymatically released by peptide N-glycosidase F [99,100] (alternatively, various lectin-affinity approaches can be used). In addition, peptide antibody-based techniques, such as stable isotope standard capture with anti-peptide antibodies $\left(\right.$ SISCAPA $\left.^{\circ}\right)[101,102]$, can be coupled to SRM-MS to enrich and quantify target peptides selectively.

\section{Into the clinic}

According to the Early Detection Research Network [103], a biomarker should undergo five major phases of development before it can be confidently utilized under clinical settings for the benefit of the population. These phases are: i) preclinical exploratory studies, during which tumor- and/or aggressive-disease-associated samples are compared to non-tumor or indolent disease specimens in order to identify molecular characteristics that distinguish both cohorts and can be further explored; ii) clinical assay development and validation, during which an assay that can accurately measure the biomarker and can reliably segregate tumor from nontumor specimens is developed; iii) retrospective longitudinal studies that utilize specimens from individuals who were monitored over time for the development or progression of disease (such as patients who progress from indolent to aggressive prostate cancer) are compared to individuals who do not develop disease or do not progress; iv) prospective screening studies that are performed using the assay in order to evaluate the extent of disease at the time of detection; and v) randomized control studies that are performed in order to determine the reduction of disease burden in the population as a result of performing the assay.

Emerging technologies that not only provide an indepth look into the complex biology of tumors but also allow timely verification and validation will undoubtedly accelerate the progress of molecular markers through the biomarker development pipeline. We and others have shown that such technologies are applicable to a variety of sample types, including bio-fluids, and can enable rapid verification of exhaustive lists of candidate biomarkers.

\section{Conclusions}

The long path from biomarker discovery to validation and clinical use has resulted in exhaustive lists of biomarker candidates but relatively few are currently used in patient management. The consensus within the field is that candidate biomarkers need to be verified rapidly using large, well-annotated sample cohorts, standardized 
assays and multi-institutional validations. Rapidly improving targeted proteomics approaches could lay the foundations for such validation platforms in the near future. The use of proximal tissue fluids (such as EPSurine) in combination with specific enrichment protocols (such as those for exosomes and glycoproteins) are especially exciting strategies that will need to be systematically evaluated. In the context of exosomes, additional cancer-specific biomolecular cargo, such as tumor-derived miRNAs and mRNAs and possible tumorDNA, could complement these studies and provide powerful multidimensional biomarker panels for the accurate detection of aggressive prostate cancers (see Figure 1 for a summary of the various biomarker pipelines).

\section{Abbreviations}

AMACR, a-methylacyl-coenzyme A racemase; EPS, expressed prostatic secretions; ETS, E twenty-six (transcription factor); miRNA, microRNA; MS/ MS, tandem mass spectrometry; PCA3, prostate cancer antigen 3; PSA, prostate-specific antigen; PTEN, phosphatase and tensin homolog; SRM-MS, selected reaction monitoring mass spectrometry; SWATH, sequential window acquisition of all theoretical fragment ion spectra; SIM, single ion monitoring; TMPRSS2, transmembrane protease serine 2 .

\section{Competing interests}

The authors have no competing interest.

\section{Acknowledgements}

TK is supported through the Canadian Research Chairs Program. YK is a recipient of an Ontario Graduate Scholarship. This work was supported by a grant from the Canadian Institute of Health Research (MOP-93772) to TK. This research was funded in part by the Ontario Ministry of Health and Long Term Care. The views expressed do not necessarily reflect those of the OMOHLTC.

\section{Author details}

'Department of Medical Biophysics, University of Toronto, Toronto, Canada M5G 1L7. 2Princess Margaret Cancer Center, University Health Network Toronto, Canada M5G 1L7.

Published: 28 June 2013

\section{References}

1. Stephenson AJ, Kattan MW, Eastham JA, Bianco FJ Jr, Yossepowitch O, Vickers AJ, Klein EA, Wood DP, Scardino PT: Prostate cancer-specific mortality after radical prostatectomy for patients treated in the prostate-specific antigen era. J Clin Oncol 2009, 27:4300-4305.

2. Jemal A, Bray F, Center MM, Ferlay J, Ward E, Forman D: Global cancer statistics. CA Cancer J Clin 2011, 61:69-90

3. Ploussard G, de la Taille A: Urine biomarkers in prostate cancer. Nat Rev Urol 2010, 7:101-109.

4. Schröder FH, Hugosson J, Roobol MJ, Tammela TL, Ciatto S, Nelen V, Kwiatkowski M, Lujan M, Lilja H, Zappa M, Denis LJ, Recker F, Berenguer A, Määttänen L, Bangma CH, Aus G, Villers A, Rebillard X, van der Kwast T, Blijenberg BG, Moss SM, de Koning HJ, Auvinen A; ERSPC Investigators: Screening and prostate-cancer mortality in a randomized European study. N Engl J Med 2009, 360:1320-1328.

5. Moyer VA: Screening for prostate cancer: U.S. Preventive Services Task Force recommendation statement. Ann Intern Med 2012, 157:120-134.

6. Shao YH, Demissie K, Shih W, Mehta AR, Stein MN, Roberts CB, Dipaola RS, Lu-Yao GL: Contemporary risk profile of prostate cancer in the United States. J Nat/ Cancer Inst 2009, 101:1280-1283.

7. Andriole GL, Crawford ED, Grubb RL 3rd, Buys SS, Chia D, Church TR, Fouad MN, Gelmann EP, Kvale PA, Reding DJ, Weissfeld JL, Yokochi LA, O'Brien B, Clapp JD, Rathmell JM, Riley TL, Hayes RB, Kramer BS, Izmirlian G, Miller AB, Pinsky PF, Prorok PC, Gohagan JK, Berg CD; PLCO Project Team: Mortality results from a randomized prostate-cancer screening trial. N Engl J Med 2009, 360:1310-1319.
8. Prensner JR, Rubin MA, Wei JT, Chinnaiyan AM: Beyond PSA: the next generation of prostate cancer biomarkers. Sci Trans/Med 2012, 4:127rv3.

9. Gleason DF, Mellinger GT: Prediction of prognosis for prostatic adenocarcinoma by combined histological grading and clinical staging. J Urol 1974, 111:58-64.

10. Martin NE, Mucci LA, Loda M, Depinho RA: Prognostic determinants in prostate cancer. Cancer J 2011, 17:429-437.

11. D'Amico AV, Whittington R, Malkowicz SB, Schultz D, Blank K, Broderick GA, Tomaszewski JE, Renshaw AA, Kaplan I, Beard CJ, Wein A: Biochemical outcome after radical prostatectomy, external beam radiation therapy, or interstitial radiation therapy for clinically localized prostate cancer. JAMA 1998, 280:969-974.

12. Stark JR, Perner S, Stampfer MJ, Sinnott JA, Finn S, Eisenstein AS, Ma J, Fiorentino M, Kurth T, Loda M, Giovannucci EL, Rubin MA, Mucci LA: Gleason score and lethal prostate cancer: does $3+4=4+3$ ? J Clin Onco/2009, 27:3459-3464

13. Glass AS, Porten SP, Bonham M, Tran TC, Cowan JE, Punnen S, Chan JM, Carroll PR: Active surveillance: does serial prostate biopsy increase histological inflammation? Prostate Cancer Prostatic Dis 2013, 16:165-169.

14. D'Amico AV, Chen MH, Catalona WJ, Sun L, Roehl KA, Moul JW: Prostate cancer-specific mortality after radical prostatectomy or external beam radiation therapy in men with 1 or more high-risk factors. Cancer 2007, 110:56-61.

15. Scholzen T, Gerdes J: The Ki- 67 protein: from the known and the unknown. J Cell Physiol 2000, 182:311-322.

16. Berney DM, Gopalan A, Kudahetti S, Fisher G, Ambroisine L, Foster CS, Reuter V, Eastham J, Moller H, Kattan MW, Gerald W, Cooper C, Scardino P, Cuzick J: $\mathrm{Ki}-67$ and outcome in clinically localised prostate cancer: analysis of conservatively treated prostate cancer patients from the Trans-Atlantic Prostate Group study. Br J Cancer 2009, 100:888-893.

17. Khor LY, Bae K, Paulus R, Al-Saleem T, Hammond ME, Grignon DJ, Che M, Venkatesan V, Byhardt RW, Rotman M, Hanks GE, Sandler HM, Pollack A: MDM2 and Ki-67 predict for distant metastasis and mortality in men treated with radiotherapy and androgen deprivation for prostate cancer: RTOG 92-02. J Clin Oncol 2009, 27:3177-3184.

18. Bettencourt MC, Bauer JJ, Sesterhenn IA, Mostofi FK, McLeod DG, Moul JW: $\mathrm{Ki}-67$ expression is a prognostic marker of prostate cancer recurrence after radical prostatectomy. J Urol 1996, 156:1064-1068.

19. Fisher G, Yang ZH, Kudahetti S, Moller H, Scardino P, Cuzick J, Berney DM: Prognostic value of Ki-67 for prostate cancer death in a conservatively managed cohort. Br J Cancer 2013, 108:271-277.

20. Murphy AJ, Hughes CA, Lannigan G, Sheils O, O'Leary J, Loftus B: Heterogeneous expression of alpha-methylacyl-CoA racemase in prostatic cancer correlates with Gleason score. Histopathology 2007, 50:243-251.

21. Rubin MA, Bismar TA, Andren O, Mucci L, Kim R, Shen R, Ghosh D, Wei JT, Chinnaiyan AM, Adami HO, Kantoff PW, Johansson JE: Decreased alphamethylacyl CoA racemase expression in localized prostate cancer is associated with an increased rate of biochemical recurrence and cancerspecific death. Cancer Epidemiol Biomarkers Prev 2005, 14:1424-1432.

22. Chang SS: Overview of prostate-specific membrane antigen. Rev Uro/ 2004, 6 (Suppl 10):S13-S18.

23. Ross JS, Sheehan CE, Fisher HA, Kaufman RP Jr, Kaur P, Gray K, Webb I, Gray GS, Mosher R, Kallakury BV: Correlation of primary tumor prostate-specific membrane antigen expression with disease recurrence in prostate cancer. Clin Cancer Res 2003, 9:6357-6362.

24. Perner S, Hofer MD, Kim R, Shah RB, Li H, Moller P, Hautmann RE, Gschwend JE, Kuefer R, Rubin MA: Prostate-specific membrane antigen expression as a predictor of prostate cancer progression. Hum Pathol 2007, 38:696-701.

25. Cuzick J, Swanson GP, Fisher G, Brothman AR, Berney DM, Reid JE, Mesher D, Speights VO, Stankiewicz E, Foster CS, Møller H, Scardino P, Warren JD, Park J, Younus A, Flake DD 2nd, Wagner S, Gutin A, Lanchbury JS, Stone S; Transatlantic Prostate Group: Prognostic value of an RNA expression signature derived from cell cycle proliferation genes in patients with prostate cancer: a retrospective study. Lancet Oncol 2011, 12:245-255.

26. Ding Z, Wu CJ, Chu GC, Xiao Y, Ho D, Zhang J, Perry SR, Labrot ES, Wu X, Lis R, Hoshida Y, Hiller D, Hu B, Jiang S, Zheng H, Stegh AH, Scott KL, Signoretti S, Bardeesy N, Wang YA, Hill DE, Golub TR, Stampfer MJ, Wong WH, Loda M, Mucci L, Chin L, DePinho RA: SMAD4-dependent barrier constrains prostate cancer growth and metastatic progression. Nature 2011, 470:269-273.

27. Taylor BS, Schultz N, Hieronymus H, Gopalan A, Xiao Y, Carver BS, Arora VK, Kaushik P, Cerami E, Reva B, Antipin Y, Mitsiades N, Landers T, Dolgalev I, Major 
JE, Wilson M, Socci ND, Lash AE, Heguy A, Eastham JA, Scher HI, Reuter VE, Scardino PT, Sander C, Sawyers CL, Gerald WL: Integrative genomic profiling of human prostate cancer. Cancer Cell 2010, 18:11-22.

28. Penney KL, Sinnott JA, Fall K, Pawitan Y, Hoshida Y, Kraft P, Stark JR, Fiorentino M, Perner S, Finn S, Calza S, Flavin R, Freedman ML, Setlur S, Sesso HD, Andersson SO, Martin N, Kantoff PW, Johansson JE, Adami HO, Rubin MA, Loda M, Golub TR, Andrén O, Stampfer MJ, Mucci LA: mRNA expression signature of Gleason grade predicts lethal prostate cancer. J Clin Oncol 2011, 29:2391-2396

29. Cottrell S, Jung K, Kristiansen G, Eltze E, Semjonow A, Ittmann M, Hartmann A, Stamey T, Haefliger C, Weiss G: Discovery and validation of 3 novel DNA methylation markers of prostate cancer prognosis. J Urol 2007, 177:1753-1758

30. Gupta A, Lotan Y, Ashfaq R, Roehrborn CG, Raj GV, Aragaki CC, Montorsi F, Shariat SF: Predictive value of the differential expression of the urokinase plasminogen activation axis in radical prostatectomy patients. Eur Urol 2009, 55:1124-1133.

31. Shariat SF, Menesses-Diaz A, Kim IY, Muramoto M, Wheeler TM, Slawin KM: Tissue expression of transforming growth factor-beta1 and its receptors: correlation with pathologic features and biochemical progression in patients undergoing radical prostatectomy. Urology 2004, 63:1 191-1197.

32. Shariat SF, Kattan MW, Traxel E, Andrews B, Zhu K, Wheeler TM, Slawin KM: Association of pre- and postoperative plasma levels of transforming growth factor beta(1) and interleukin 6 and its soluble receptor with prostate cancer progression. Clin Cancer Res 2004, 10:1992-1999.

33. Wood DP Jr, Banerjee M: Presence of circulating prostate cells in the bone marrow of patients undergoing radical prostatectomy is predictive of disease-free survival. J Clin Oncol 1997, 15:3451-3457.

34. Berg A, Berner A, Lilleby W, Bruland OS, Fossa SD, Nesland JM, Kvalheim G: Impact of disseminated tumor cells in bone marrow at diagnosis in patients with nonmetastatic prostate cancer treated by definitive radiotherapy. Int J Cancer 2007, 120:1603-1609.

35. Kantoff PW, Halabi S, Farmer DA, Hayes DF, Vogelzang NA, Small EJ: Prognostic significance of reverse transcriptase polymerase chain reaction for prostate-specific antigen in men with hormone-refractory prostate cancer. J Clin Oncol 2001, 19:3025-3028.

36. Goodman OB Jr, Fink LM, Symanowski JT, Wong B, Grobaski B, Pomerantz D, Ma Y, Ward DC, Vogelzang NJ: Circulating tumor cells in patients with castration-resistant prostate cancer baseline values and correlation with prognostic factors. Cancer Epidemiol Biomarkers Prev 2009, 18:1904-1913.

37. Porkka KP, Pfeiffer MJ, Waltering KK, Vessella RL, Tammela TL, Visakorpi T: MicroRNA expression profiling in prostate cancer. Cancer Res 2007. 67:6130-6135

38. Mitchell PS, Parkin RK, Kroh EM, Fritz BR, Wyman SK, Pogosova-Agadjanyan EL, Peterson A, Noteboom J, O'Briant KC, Allen A, Lin DW, Urban N, Drescher CW, Knudsen BS, Stirewalt DL, Gentleman R, Vessella RL, Nelson PS, Martin DB, Tewari M: Circulating microRNAs as stable blood-based markers for cancer detection. Proc Natl Acad SciU S A 2008, 105:10513-10518.

39. Khan AP, Poisson LM, Bhat VB, Fermin D, Zhao R, Kalyana-Sundaram S, Michailidis G, Nesvizhskii Al, Omenn GS, Chinnaiyan AM, Sreekumar A: Quantitative proteomic profiling of prostate cancer reveals a role for miR-128 in prostate cancer. Mol Cell Proteomics 2010, 9:298-312.

40. Sreekumar A, Poisson LM, Rajendiran TM, Khan AP, Cao Q, Yu J, Laxman B, Mehra R, Lonigro RJ, Li Y, Nyati MK, Ahsan A, Kalyana-Sundaram S, Han B, Cao X, Byun J, Omenn GS, Ghosh D, Pennathur S, Alexander DC, Berger A, Shuster JR, Wei JT, Varambally S, Beecher C, Chinnaiyan AM: Metabolomic profiles delineate potential role for sarcosine in prostate cancer progression. Nature 2009, 457:910-914.

41. Zhou X, Mao J, Ai J, Deng Y, Roth MR, Pound C, Henegar J, Welti R, Bigler SA: Identification of plasma lipid biomarkers for prostate cancer by lipidomics and bioinformatics. PLoS One 2012, 7:e48889.

42. Rifai N, Gillette MA, Carr SA: Protein biomarker discovery and validation: the long and uncertain path to clinical utility. Nat Biotechnol 2006, 24:971-983.

43. Omenn GS: The Human Proteome Organization Plasma Proteome Project pilot phase: reference specimens, technology platform comparisons, and standardized data submissions and analyses. Proteomics 2004, 4:1235-1240.

44. Teng PN, Bateman NW, Hood BL, Conrads TP: Advances in proximal fluid proteomics for disease biomarker discovery. J Proteome Res 2010, 9:6091-6100

45. Theodorescu D, Schiffer E, Bauer HW, Douwes F, Eichhorn F, Polley R, Schmidt T, Schofer W, Zurbig P, Good DM Coon JJ, Mischak H: Discovery and validation of urinary biomarkers for prostate cancer. Proteomics Clin Appl 2008, 2:556-570

46. Bussemakers MJ, van Bokhoven A, Verhaegh GW, Smit FP, Karthaus HF, Schalken JA, Debruyne FM, Ru N, Isaacs WB: DD3: a new prostate-specific gene, highly overexpressed in prostate cancer. Cancer Res 1999, 59:5975-5979

47. Groskopf J, Aubin SM, Deras IL, Blase A, Bodrug S, Clark C, Brentano S, Mathis J, Pham J, Meyer T, Cass M, Hodge P, Macairan ML, Marks LS, Rittenhouse H: APTIMA PCA3 molecular urine test: development of a method to aid in the diagnosis of prostate cancer. Clin Chem 2006, 52:1089-1095.

48. Nakanishi H, Groskopf J, Fritsche HA, Bhadkamkar V, Blase A, Kumar SV, Davis JW, Troncoso P, Rittenhouse H, Babaian RJ: PCA3 molecular urine assay correlates with prostate cancer tumor volume: implication in selecting candidates for active surveillance. J Uro/ 2008, 179:1804-1809; discussion 1809-1810.

49. Whitman EJ, Groskopf J, Ali A, Chen Y, Blase A, Furusato B, Petrovics G, Ibrahim M, Elsamanoudi S, Cullen J, Sesterhenn IA, Brassell S, Rittenhouse H, Srivastava S, McLeod DG: PCA3 score before radical prostatectomy predicts extracapsular extension and tumor volume. J Urol 2008, 180:1975-1978; discussion 1978-1979.

50. Augustin H, Mayrhofer K, Pummer K, Mannweiler S: Relationship between prostate cancer gene 3 (PCA3) and characteristics of tumor aggressiveness. Prostate 2013, 73:203-210.

51. Tomlins SA, Rhodes DR, Perner S, Dhanasekaran SM, Mehra R, Sun XW, Varambally S, Cao X, Tchinda J, Kuefer R, Lee C, Montie JE, Shah RB, Pienta KJ, Rubin MA, Chinnaiyan AM: Recurrent fusion of TMPRSS2 and ETS transcription factor genes in prostate cancer. Science 2005, 310:644-648.

52. Laxman B, Tomlins SA, Mehra R, Morris DS, Wang L, Helgeson BE, Shah RB, Rubin MA, Wei JT, Chinnaiyan AM: Noninvasive detection of TMPRSS2:ERG fusion transcripts in the urine of men with prostate cancer. Neoplasia 2006 8:885-888.

53. Hessels D, Smit FP, Verhaegh GW, Witjes JA, Cornel EB, Schalken JA: Detection of TMPRSS2-ERG fusion transcripts and prostate cancer antigen 3 in urinary sediments may improve diagnosis of prostate cancer. Clin Cancer Res 2007, 13:5103-5108.

54. Shay JW, Wright WE: Telomerase activity in human cancer. Curr Opin Oncol 1996, 8:66-71.

55. Meid FH, Gygi CM, Leisinger HJ, Bosman FT, Benhattar J: The use of telomerase activity for the detection of prostatic cancer cells after prostatic massage. J Urol 2001, 165:1802-1805.

56. Kim NW, Wu F: Advances in quantification and characterization of telomerase activity by the telomeric repeat amplification protocol (TRAP). Nucleic Acids Res 1997, 25:2595-2597.

57. Schostak M, Schwall GP, Poznanovic S, Groebe K, Muller M, Messinger D, Miller K, Krause H, Pelzer A, Horninger W, Klocker H, Hennenlotter J, Feyerabend S, Stenzl A, Schrattenholz A: Annexin A3 in urine: a highly specific noninvasive marker for prostate cancer early detection. J Urol 2009, 181:343-353.

58. Egeblad M, Werb Z: New functions for the matrix metalloproteinases in cancer progression. Nat Rev Cancer 2002, 2:161-174.

59. Roy R, Louis G, Loughlin KR, Wiederschain D, Kilroy SM, Lamb CC, Zurakowski D, Moses MA: Tumor-specific urinary matrix metalloproteinase fingerprinting: identification of high molecular weight urinary matrix metalloproteinase species. Clin Cancer Res 2008, 14:6610-6617.

60. Di Carlo A, Mariano A, Terracciano D, Ferro M, Montanaro V, Marsicano M, Di Lorenzo G, Altieri V, Macchia V: Matrix metalloproteinase-2 and -9 in the urine of prostate cancer patients. Oncol Rep 2010, 24:3-8.

61. Zhou H, Yuen PS, Pisitkun T, Gonzales PA, Yasuda H, Dear JW, Gross P, Knepper MA, Star RA: Collection, storage, preservation, and normalization of human urinary exosomes for biomarker discovery. Kidney Int 2006, 69:1471-1476.

62. Duijvesz $\mathrm{D}$, Luider T, Bangma $\mathrm{CH}$, Jenster $\mathrm{G}$ : Exosomes as biomarker treasure chests for prostate cancer. Eur Urol 2011, 59:823-831.

63. Nilsson J, Skog J, Nordstrand A, Baranov V, Mincheva-Nilsson L, Breakefield XO, Widmark A: Prostate cancer-derived urine exosomes: a novel approach to biomarkers for prostate cancer. Br J Cancer 2009, 100:1603-1607.

64. Vlassov AV, Magdaleno S, Setterquist R, Conrad R: Exosomes: current knowledge of their composition, biological functions, and diagnostic and therapeutic potentials. Biochim Biophys Acta 2012, 1820:940-948.

65. Wang Z, Hill S, Luther JM, Hachey DL, Schey KL: Proteomic analysis of urine exosomes by multidimensional protein identification technology (MudPIT). Proteomics 2012, 12:329-338.

66. Mitchell PJ, Welton J, Staffurth J, Court J, Mason MD, Tabi Z, Clayton A: 
Can urinary exosomes act as treatment response markers in prostate cancer? J Trans/ Med 2009, 7:4.

67. Skog J, Wurdinger T, van Rijn S, Meijer DH, Gainche L, Sena-Esteves M, Curry WT Jr, Carter BS, Krichevsky AM, Breakefield XO: Glioblastoma microvesicles transport RNA and proteins that promote tumour growth and provide diagnostic biomarkers. Nat Cell Biol 2008, 10:1470-1476.

68. Taylor DD, Gercel-Taylor C: MicroRNA signatures of tumor-derived exosomes as diagnostic biomarkers of ovarian cancer. Gynecol Oncol 2008 110:13-21.

69. Valadi H, Ekstrom K, Bossios A, Sjostrand M, Lee JJ, Lotvall JO: Exosomemediated transfer of mRNAs and microRNAs is a novel mechanism of genetic exchange between cells. Nat Cell Biol 2007, 9:654-659.

70. Li R, Guo Y, Han BM, Yan X, Utleg AG, Li W, Tu LC, Wang J, Hood L, Xia S, Lin B: Proteomics cataloging analysis of human expressed prostatic secretions reveals rich source of biomarker candidates. Proteomics Clin Appl 2008, 2:543-555.

71. Drake RR, Elschenbroich S, Lopez-Perez O, Kim Y, Ignatchenko V, Ignatchenko A, Nyalwidhe JO, Basu G, Wilkins CE, Gjurich B, Lance RS, Semmes OJ, Medin $J A$, Kislinger T: In-depth proteomic analyses of direct expressed prostatic secretions. J Proteome Res 2010, 9:2109-2116.

72. Wolters DA, Washburn MP, Yates JR 3rd: An automated multidimensional protein identification technology for shotgun proteomics. Anal Chem 2001, 73:5683-5690.

73. Washburn MP, Wolters D, Yates JR 3rd: Large-scale analysis of the yeast proteome by multidimensional protein identification technology. Nat Biotechnol 2001, 19:242-247.

74. Zhao T, Zeng X, Bateman NW, Sun M, Teng PN, Bigbee WL, Dhir R, Nelson JB, Conrads TP, Hood BL: Relative quantitation of proteins in expressed prostatic secretion with a stable isotope labeled secretome standard. J Proteome Res 2012, 11:1089-1099.

75. Principe S, Kim Y, Fontana S, Ignatchenko V Nyalwidhe JO, Lance RS, Troyer DA, Alessandro R, Semmes OJ, Kislinger T, Drake RR, Medin JA: Identification of prostate-enriched proteins by in-depth proteomic analyses of expressed prostatic secretions in urine. J Proteome Res 2012, 11:2386-2396.

76. Adachi J, Kumar C, Zhang Y, Olsen JV, Mann M: The human urinary proteome contains more than 1500 proteins, including a large proportion of membrane proteins. Genome Biol 2006, 7:R80.

77. Kagedan D, Lecker I, Batruch I, Smith C, Kaploun I, Lo K, Grober E, Diamandis $E P$, Jarvi KA: Characterization of the seminal plasma proteome in men with prostatitis by mass spectrometry. Clin Proteomics 2012, 9:2.

78. Luo LY, Shan SJ, Elliott MB, Soosaipillai A, Diamandis EP: Purification and characterization of human kallikrein 11 , a candidate prostate and ovarian cancer biomarker, from seminal plasma. Clin Cancer Res 2006, 12:742-750.

79. Kondrat KL, McClusky GA, Cooks RG: Multiple reaction monitoring mass spectrometry/mass spectrometry for direct analysis of complex mixtures. Anal Chem 1978:2017-2021.

80. Anderson L, Hunter $\mathrm{CL}$ : Quantitative mass spectrometric multiple reaction monitoring assays for major plasma proteins. Mol Cell Proteomics 2006, 5:573-588.

81. Keshishian H, Addona T, Burgess M, Kuhn E, Carr SA: Quantitative, multiplexed assays for low abundance proteins in plasma by targeted mass spectrometry and stable isotope dilution. Mol Cell Proteomics 2007, 6:2212-2229.

82. Addona TA, Abbatiello SE, Schilling B, Skates SJ, Mani DR, Bunk DM Spiegelman CH, Zimmerman LJ, Ham AJ, Keshishian H, Hall SC, Allen S, Blackman RK, Borchers CH, Buck C, Cardasis HL, Cusack MP, Dodder NG, Gibson BW, Held JM, Hiltke T, Jackson A, Johansen EB, Kinsinger CR, Li J, Mesri M, Neubert TA, Niles RK, Pulsipher TC, Ransohoff D, et al:: Multi-site assessment of the precision and reproducibility of multiple reaction monitoring-based measurements of proteins in plasma. Nat Biotechnol 2009, 27:633-641.

83. Selevsek N, Matondo M, Sanchez Carbayo M, Aebersold R, Domon B: Systematic quantification of peptides/proteins in urine using selected reaction monitoring. Proteomics 2011, 11:1135-1147.

84. Elschenbroich S, Ignatchenko V, Clarke B, Kalloger SE, Boutros PC, Gramolini AO, Shaw P, Jurisica I, Kislinger T: In-depth proteomics of ovarian cancer ascites: combining shotgun proteomics and selected reaction monitoring mass spectrometry. J Proteome Res 2011, 10:2286-2299.

85. Wei Y, Tong J, Taylor P, Strumpf D, I gnatchenko V, Pham NA, Yanagawa N, Liu G, Jurisica I, Shepherd FA, Tsao MS, Kislinger T, Moran MF: Primary tumor xenografts of human lung adeno and squamous cell carcinoma express distinct proteomic signatures. J Proteome Res 2011, 10:161-174.

86. Cima I, Schiess R, Wild P, Kaelin M, Schüffler P, Lange V, Picotti P, Ossola R, Templeton A, Schubert O, Fuchs T, Leippold T, Wyler S, Zehetner J, Jochum W, Buhmann J, Cerny T, Moch H, Gillessen S, Aebersold R, Krek W: Cancer genetics-guided discovery of serum biomarker signatures for diagnosis and prognosis of prostate cancer. Proc Natl Acad Sci U S A 2011, 108:3342-3347.

87. Hüttenhain R, Soste M, Selevsek N, Röst H, Sethi A, Carapito C, Farrah T, Deutsch EW, Kusebauch U, Moritz RL, Niméus-Malmström E, Rinner O, Aebersold R: Reproducible quantification of cancer-associated proteins in body fluids using targeted proteomics. Sci Trans/ Med 2012, 4:142-194.

88. Kim Y, Ignatchenko V, Yao CQ, Kalatskaya I, Nyalwidhe JO, Lance RS, Gramolini AO, Troyer DA, Stein LD, Boutros PC, Medin JA, Semmes OJ, Drake RR, Kislinger $\mathrm{T}$ : Identification of differentially expressed proteins in direct expressed prostatic secretions of men with organ-confined versus extracapsular prostate cancer. Mol Cell Proteomics 2012, 11:1870-1884.

89. Venable JD, Dong MQ, Wohlschlegel J, Dillin A, Yates JR: Automated approach for quantitative analysis of complex peptide mixtures from tandem mass spectra. Nat Methods 2004, 1:39-45.

90. Gillet LC, Navarro P, Tate S, Rost H, Selevsek N, Reiter L, Bonner R, Aebersold R: Targeted data extraction of the MS/MS spectra generated by dataindependent acquisition: a new concept for consistent and accurate proteome analysis. Mol Cell Proteomics 2012, 11:0111 016717.

91. Liu Y, Huttenhain R, Surinova S, Gillet LC, Mouritsen J, Brunner R, Navarro P, Aebersold R: Quantitative measurements of $\mathrm{N}$-linked glycoproteins in human plasma by SWATH-MS. Proteomics 2013, 13:1247-1256.

92. Sherman J, McKay MJ, Ashman K, Molloy MP: How specific is my SRM? The issue of precursor and product ion redundancy. Proteomics 2009, 9:1120-1123.

93. Abbatiello SE, Mani DR, Keshishian H, Carr SA: Automated detection of inaccurate and imprecise transitions in peptide quantification by multiple reaction monitoring mass spectrometry. Clin Chem 2010, 56:291-305.

94. Gallien S, Duriez E, Crone C, Kellmann M, Moehring T, Domon B: Targeted proteomic quantification on quadrupole-orbitrap mass spectrometer. Mol Cell Proteomics 2012, 11:1709-1723.

95. Fredolini C, Meani F, Luchini A, Zhou W, Russo P, Ross M, Patanarut A Tamburro D, Gambara G, Ornstein D, Odicino F, Ragnoli M, Ravaggi A, Novelli F, Collura D, D'Urso L, Muto G, Belluco C, Pecorelli S, Liotta L, Petricoin EF 3rd: Investigation of the ovarian and prostate cancer peptidome for candidate early detection markers using a novel nanoparticle biomarker capture technology. AAPS J 2010, 12:504-518.

96. Longo C, Patanarut A, George T, Bishop B, Zhou W, Fredolini C, Ross MM, Espina V, Pellacani G, Petricoin EF 3rd, Liotta LA, Luchini A: Core-shell hydrogel particles harvest, concentrate and preserve labile low abundance biomarkers. PLoS One 2009, 4:e4763.

97. Tamburro D, Fredolini C, Espina V, Douglas TA, Ranganathan A, llag L, Zhou W Russo P, Espina BH, Muto G, Petricoin EF 3rd, Liotta LA, Luchini A: Multifunctional core-shell nanoparticles: discovery of previously invisible biomarkers. J Am Chem Soc 2011, 133:19178-19188

98. Roth J: Protein N-glycosylation along the secretory pathway: relationship to organelle topography and function, protein quality control, and cell interactions. Chem Rev 2002, 102:285-303.

99. Tian Y, Zhou Y, Elliott S, Aebersold R, Zhang H: Solid-phase extraction of N-linked glycopeptides. Nat Protoc 2007, 2:334-339.

100. Zhang H, Li XJ, Martin DB, Aebersold R: Identification and quantification of $\mathrm{N}$-linked glycoproteins using hydrazide chemistry, stable isotope labeling and mass spectrometry. Nat Biotechnol 2003, 21:660-666.

101. Anderson NL, Anderson NG, Haines LR, Hardie DB, Olafson RW, Pearson TW: Mass spectrometric quantitation of peptides and proteins using stable isotope standards and capture by anti-peptide antibodies (SISCAPA). J Proteome Res 2004, 3:235-244.

102. Anderson NL, Jackson A, Smith D, Hardie D, Borchers C, Pearson TW: SISCAPA peptide enrichment on magnetic beads using an in-line bead trap device. Mol Cell Proteomics 2009, 8:995-1005.

103. Pepe MS, Etzioni R, Feng Z, Potter JD, Thompson ML, Thornquist M, Winget M, Yasui Y: Phases of biomarker development for early detection of cancer. J Natl Cancer Inst 2001, 93:1054-1061.

104. Alaiya AA, Al-Mohanna M, Aslam M, Shinwari Z, Al-Mansouri L, Al-Rodayan M, Al-Eid M, Ahmad I, Hanash K, Tulbah A, Bin Mahfooz A, Adra C: Proteomicsbased signature for human benign prostate hyperplasia and prostate 
adenocarcinoma. Int J Oncol 2011, 38:1047-1057.

105. Pang J, Liu WP, Liu XP, Li LY, Fang YQ, Sun QP, Liu SJ, Li MT, Su ZL, Gao X: Profiling protein markers associated with lymph node metastasis in prostate cancer by DIGE-based proteomics analysis. J Proteome Res 2010, 9:216-226.

106. Skvortsov S, Schafer G, Stasyk T, Fuchsberger C, Bonn GK, Bartsch G, Klocker H, Huber LA: Proteomics profiling of microdissected low- and high-grade prostate tumors identifies Lamin A as a discriminatory biomarker. J Proteome Res 2011, 10:259-268.

107. Wang D, Liang H, Mao X, Liu W, Li M, Qiu S: Changes of transthyretin and clusterin after androgen ablation therapy and correlation with prostate cancer malignancy. Trans/ Oncol 2012, 5:124-132.

108. Drake JM, Graham NA, Stoyanova T, Sedghi A, Goldstein AS, Cai H, Smith DA, Zhang H, Komisopoulou E, Huang J, Graeber TG, Witte ON: Oncogenespecific activation of tyrosine kinase networks during prostate cancer progression. Proc Natl Acad Sci U S A 2012, 109:1643-1648.
109. Rehman I, Evans CA, Glen A, Cross SS, Eaton CL, Down J, Pesce G, Phillips JT, Yen OS, Thalmann GN, Wright PC, Hamdy FC: iTRAQ identification of candidate serum biomarkers associated with metastatic progression of human prostate cancer. PLoS One 2012, 7:e30885.

110. Saraon P, Cretu D, Musrap N, Karagiannis GS, Batruch I, Drabovich AP, van der Kwast T, Mizokami A, Morrissey C, Jarvi K, Diamandis EP: Quantitative proteomics reveals that enzymes of the ketogenic pathway are associated with prostate cancer progression. Mol Cell Proteomics 2013, 12:1589-1601.

111. Yocum AK, Khan AP, Zhao R, Chinnaiyan AM: Development of selected reaction monitoring-MS methodology to measure peptide biomarkers in prostate cancer. Proteomics 2010, 10:3506-3514.

doi:10.1186/gm460

Cite this article as: Kim Y, Kislinger T: Novel approaches for the identification of biomarkers of aggressive prostate cancer. Genome Medicine 2013, 5:56. 